\title{
De invloed van voortijdige schooluitval op de instroomprognoses van schoolverlaters op de arbeidsmarkt
}

Citation for published version (APA):

Cörvers, F. (2003). De invloed van voortijdige schooluitval op de instroomprognoses van schoolverlaters op de arbeidsmarkt. Researchcentrum voor Onderwijs en Arbeidsmarkt, Faculteit der Economische Wetenschappen. ROA Working Papers No. 1 https://doi.org/10.26481/umarow.2003001

Document status and date:

Published: 01/01/2003

DOI:

10.26481/umarow.2003001

Document Version:

Publisher's PDF, also known as Version of record

Please check the document version of this publication:

- A submitted manuscript is the version of the article upon submission and before peer-review. There can be important differences between the submitted version and the official published version of record.

People interested in the research are advised to contact the author for the final version of the publication, or visit the DOI to the publisher's website.

- The final author version and the galley proof are versions of the publication after peer review.

- The final published version features the final layout of the paper including the volume, issue and page numbers.

Link to publication

\footnotetext{
General rights rights.

- You may freely distribute the URL identifying the publication in the public portal. please follow below link for the End User Agreement:

www.umlib.nl/taverne-license

Take down policy

If you believe that this document breaches copyright please contact us at:

repository@maastrichtuniversity.nl

providing details and we will investigate your claim.
}

Copyright and moral rights for the publications made accessible in the public portal are retained by the authors and/or other copyright owners and it is a condition of accessing publications that users recognise and abide by the legal requirements associated with these

- Users may download and print one copy of any publication from the public portal for the purpose of private study or research.

- You may not further distribute the material or use it for any profit-making activity or commercial gain

If the publication is distributed under the terms of Article $25 \mathrm{fa}$ of the Dutch Copyright Act, indicated by the "Taverne" license above, 


\title{
De invloed van voortijdige schooluitval op de instroomprognoses van schoolverlaters op de arbeidsmarkt
}

\author{
ROA-W-2003/1
}

Frank Cörvers, Bart Golsteyn

Researchcentrum voor Onderwijs en Arbeidsmarkt

Faculteit der Economische Wetenschappen en Bedrijfskunde Universiteit Maastricht

Maastricht, januari 2003 
ISBN 90-5321-353-8

Sec02.220.doc 
Inhoud

Pagina

Voorwoord

1 Inleiding 1

2 Methodiek van de reconstructie van onderwijsloopbanen 3

3 De reconstructie vergeleken met de EBB 6

4 De instroomprognoses vergeleken met de referentieraming en de EBB 8

5 Samenvatting 11

$\begin{array}{ll}\text { Literatuur } & 13\end{array}$

$\begin{array}{ll}\text { Appendix A } & 15\end{array}$

$\begin{array}{ll}\text { Appendix B } & 17\end{array}$

$\begin{array}{ll}\text { Appendix C } & 19\end{array}$ 



\section{Voorwoord}

Dit onderzoek is een studie over de methodiek van de prognoses van de instroom op de arbeidsmarkt. Het onderzoek is uitgevoerd in het kader van Project Onderwijs-Arbeidsmarkt. Behalve de auteurs heeft ook Rolf van der Velden van het ROA bijgedragen aan de totstandkoming van het voorliggende werkdocument. Onze dank gaat uit naar de leden van de POA-begeleidingscommissie voor hun commentaar op een eerdere versie van het werkdocument. Bovendien willen we Gert Korteweg van het Ministerie van OCenW bedanken voor zijn medewerking aan het inzichtelijk maken van de gehanteerde prognosemethodiek door OCenW, en Frank Blom en Rob Kapel van het CBS voor de uitleg over de methodiek van de Onderwijsmatrix.

Het Project Onderwijs-Arbeidsmarkt wordt gefinancierd door het Centrum voor Werk en Inkomen (CWI), het Ministerie van Onderwijs, Cultuur en Wetenschappen, het Ministerie van Landbouw, Natuurbeheer en Visserij, het LDC Expertisecentrum voor Loopbaanvraagstukken, de Vereniging Kenniscentra Beroepsonderwijs Bedrijfsleven (COLO) en de BVE Raad. 



\section{Inleiding}

In dit werkdocument wordt getracht om beter zicht te krijgen op de kwaliteit van de prognoses van de arbeidsmarktinstroom van schoolverlaters en afgestudeerden zoals die door het ROA worden samengesteld voor de tweejaarlijkse rapportage De arbeidsmarkt naar opleiding en beroep tot 2006 (ROA, 2001). ${ }^{1}$ De aanleiding hiervoor was dat bij het samenstellen van de laatste middellangetermijnprognoses van de arbeidsmarkt tot 2006 het vermoeden rees dat het aantal ongediplomeerde schoolverlaters overschat wordt. De oorzaak hiervoor zou gelegen kunnen zijn in een gebrekkige registratie van de ongediplomeerde uitstroom uit het onderwijs. Dit heeft tot gevolg dat niet volledig duidelijk is hoeveel schoolverlaters het onderwijs zonder diploma al dan niet tijdelijk verlaten, en hoeveel onder hen later weer elders in het onderwijs terugstromen. Als gevolg van de gebrekkige registratie van ongediplomeerden zouden dubbeltellingen van leerlingen en studenten kunnen optreden, waardoor de totale instroom op de arbeidsmarkt overschat wordt. Daarnaast zou een overschatting van het percentage HBO- en WOongediplomeerden die het onderwijs verlaten kunnen leiden tot een te hoge arbeidsmarktinstroom van schoolverlaters met een HAVO/VWO-diploma als hoogst voltooide opleiding.

Met de komst van het onderwijsnummer zal het naar verwachting mogelijk worden om goed zicht krijgen op de volledige onderwijsloopbanen van leerlingen en studenten. Het gaat echter nog enige tijd duren voordat het onderwijsnummer overal is ingevoerd en voordat op basis van het onderwijsnummer betrouwbare statistieken kunnen worden samengesteld over de in-, door- en uitstroom van leerlingen en studenten in het onderwijs. ${ }^{2}$ Bij het samenstellen van de middellangetermijnprognoses van de arbeidsmarktinstroom van schoolverlaters en afgestudeerden door het ROA kan dan eveneens gebruik worden gemaakt van de informatie die beschikbaar komt met de invoering van het onderwijsnummer.

In dit werkdocument wordt op twee andere manieren getracht om de kwaliteit van de instroomprognoses te analyseren. Ten eerste worden de onderwijsloopbanen van twee vijfjaarscohorten gereconstrueerd op basis van de onderwijsmatrices van het Centraal Bureau voor de Statistiek (CBS). Hierbij wordt in principe dezelfde methodiek gebruikt als bij het samenstellen van de prognoses van de arbeidsmarktinstroom voor de middellange termijn. Ondanks dat er daarbij noodgedwongen - door het ontbreken van het onderwijsnummer - enkele grove veronderstellingen worden gemaakt ten aanzien van de stromen in en uit het onderwijs en de doorstroom, kunnen er toch enkele conclusies worden getrokken over de kwaliteit van de methodiek door een vergelijking te maken met de verdeling naar opleidingsniveau voor de dezelfde vijfjaarcohorten volgens de Enquête Beroepsbevolking (EBB) van het CBS. Deze conclusies betreffen de impliciete diplomarendementen per

1. Zie voor de methodiek bijv. Methodiek arbeidsmarktprognoses en -indicatoren 2001-2006, ROA, Maastricht, 2002.

2. Een andere mogelijkheid om gegevens te verzamelen over de ongediplomeerde uitstroom uit het onderwijs biedt de registratie van ongediplomeerden bij de Regionale Meldingscentra (RMC's). Ook deze registratie moet nog goed op gang komen. Zie ook Allen, Huijgen en Welters (2001) over een pilotstudie naar voortijdig schoolverlaters. 
opleidingsniveau en het belang van de terugstroom in het onderwijs na een tijdelijke onderbreking van de onderwijsloopbaan. Overigens wordt bij de reconstructie de verdeling naar opleidingsniveau van de vijfjaarscohorten bepaald op basis van de hoogst voltooide initiële opleiding. Bij de vergelijking met de EBB-gegevens moet ermee rekening worden gehouden dat bij de verdeling naar hoogst voltooide opleiding ook de post-initiële opleidingen meegerekend worden in de EBB.

Ten tweede wordt getracht om de prognoses die het ROA samenstelt over instroom van schoolverlaters en studenten op de arbeidsmarkt te vergelijken met soortgelijke prognoses die het Ministerie van Onderwijs, Cultuur en Wetenschappen (OCenW) opstelt in het kader van de Referentieraming. ${ }^{3}$ Evenals bij de reconstructie gaat het hier alleen om het initiële onderwijs. Echter, in tegenstelling tot de reconstructie worden geen leeftijdscohorten gevolgd in de verleden tijd, maar worden leerlingen en studenten in een prognoseperiode 'gevolgd'. Het grootste deel van hen participeert in het jaar van het opstellen van de prognoses nog in het onderwijs. ${ }^{4}$ Deze leerlingen en studenten stromen in de prognoseperiode (vijf jaar) uit het onderwijs en worden gerekend tot de instroom op de arbeidsmarkt. Zij worden derhalve niet toegerekend aan een leeftijdscohort zoals bij de reconstructie. De instroomprognoses van het ROA kunnen worden vergeleken met zowel de referentieraming van het Ministerie van OCenW als de gegevens uit de EBB.

Het doel van dit rapport is om afwijkingen in de verdeling van schoolverlaters en afgestudeerden over de opleidingsniveaus te verklaren en mogelijke verbeteringen in de prognosemethodiek te vinden. Zoals zal blijken, is de middellangetermijnprognose van het aantal HAVO/VWO-schoolverlaters vrij hoog. Dit zou kunnen komen door een overschatting van het aantal voortijdige schoolverlaters van het $\mathrm{HBO}$ en WO. De prognose van de arbeidsmarktinstroom van HAVO/VWO-schoolverlaters bestaat immers voor het grootste gedeelte uit schoolverlaters die niet slagen voor een vervolgopleiding en derhalve met het opleidingsniveau van de eerder afgeronde opleiding op de arbeidsmarkt instromen. Het hoge aantal ongediplomeerde schoolverlaters kan ontstaan door (1) een onderschatting van de diplomarendementen of (2) het onterecht beschouwen van ongediplomeerde doorstromers als ongediplomeerde schooluitval.

De omvang van de verwachte arbeidsmarktinstroom van ongediplomeerden wordt in de huidige methodiek bepaald op basis van de eerder genoemde Referentieraming van het Ministerie van OCenW. Indien de omvang van de ongediplomeerde instroom op de arbeidsmarkt overschat wordt in de Referentieraming, dan uit dit zich in een te hoog totaal aantal gediplomeerde én en naar hoogst voltooide vooropleiding herleide ongediplomeerde schoolverlaters. Zoals eerder gesteld zal in dit werkdocument de uitstroom uit het onderwijs berekend worden met behulp van een reconstructie. Hierbij zullen cohorten personen met dezelfde leeftijd gevolgd worden vanaf het moment dat zij het basisonderwijs verlaten tot

3. Zie bijvoorbeeld Ministerie van OCenW (2002).

4. Daarnaast zijn er op dat moment ook personen die werken, en vervolgens in het onderwijs terugstromen. Zij worden tot de arbeidsmarktinstroom gerekend voor zover ze het onderwijs binnen de prognoseperiode weer verlaten, met of zonder diploma. 
aan het moment dat zij het initiële onderwijs als geheel verlaten. De analyse kan meer inzicht geven in het totaal aantal schoolverlaters en de verdeling over de opleidingsniveaus.

De herleiding van de ongediplomeerde schoolverlaters naar hun hoogst behaalde vooropleiding is gebaseerd op de Onderwijsmatrix van het CBS, en uitvoerig beschreven in diverse werkdocumenten van het ROA. ${ }^{5}$ Deze onderwijsmatrix is gebaseerd op de zogenaamde 1-oktober tellingen. Een probleem bij deze tellingen is de registratie van leerlingen en studenten die voortijdig stoppen met hun studie maar korte of langere tijd later weer instromen in het onderwijs. In de Onderwijsmatrix worden zij dan als ongediplomeerde uitstroom uit het onderwijs geteld terwijl zij in feite ongediplomeerde door- of terugstromers zijn. De consequenties van dit gegeven zullen in dit rapport worden onderzocht. Dit zal worden gedaan door te corrigeren voor de personen die indirect instromen in het onderwijs, dat wil zeggen terugstromen in het onderwijs na een korte of langere tijd.

In paragraaf 2 wordt stilgestaan bij de methodiek van de reconstructie, waarna in paragraaf 3 de resultaten van de reconstructie volgen. Vervolgens worden in paragraaf 4 de instroomprognoses van het ROA vergeleken met die van het Ministerie van OCenW en met de EBB. In paragraaf 5 volgen de conclusies.

\section{Methodiek van de reconstructie van onderwijsloopbanen}

Met behulp van integrale tellingen uit de onderwijsmatrices worden de schoolloopbanen van tien jaarcohorten gevolgd vanaf het moment dat zij het basisonderwijs verlaten totdat zij het initiële onderwijs verlaten. De tien jaarcohorten zullen uiteindelijk worden geaggregeerd tot twee vijfjaarscohorten. Deze stromen zijn voor ongediplomeerde schoolverlaters moeilijker te inventariseren dan voor gediplomeerde schoolverlaters. Immers, de uitstroom uit het onderwijs wordt weliswaar waargenomen voor zowel gediplomeerden als ongediplomeerden maar van de laatste groep dient ook de vooropleiding achterhaald te worden. ${ }^{6} \mathrm{Bij}$ de reconstructie van de onderwijsloopbanen worden ongeveer dezelfde bronnen en methodiek gehanteerd als bij de ROA-prognoses van de instroom van schoolverlaters van het initiële onderwijs op de arbeidsmarkt. Bij de reconstructie worden echter de stromen in het onderwijs toegerekend aan jaarcohorten. Een ander verschil is dat in de prognoses de aantallen gediplomeerde en ongediplomeerde schoolverlaters uit de Referentieraming genomen worden, terwijl bij de reconstructie zowel de gediplomeerden als de ongediplomeerden met behulp van de onderwijsmatrices van het CBS worden vastgesteld.

5. Zie Cörvers et al. (2002) en De Grip en Jacobs (1999).

6. Bijvoorbeeld bij het ongediplomeerd verlaten van een $\mathrm{MBO}$-opleiding kan de vooropleiding HAVO/VWO met diploma zijn, maar ook een langere loopbaan zoals eerst VMBO met diploma en vervolgens HAVO/VWO zonder diploma. In de methodiek van de reconstructie wordt hiermee rekening gehouden. 
Tabel 2.1

Onderwijsstromen: basisonderwijs naar vervolgonderwijs en uitstroom

Leeftijd in
$\mathbf{2 0 0 0}$

Bron: Onderwijsmatrices 1978-1987

Tabel 2.1 toont de basisaantallen van de verdere analyse, namelijk de instroom vanuit het basisonderwijs in het vervolgonderwijs en de uitstroom uit het onderwijs (uitstroom) voor de twee vijfjaarscohorten. Zo is in de eerste rij te zien dat degenen die 34 jaar oud zijn (in 2000), het basisonderwijs in 1978 verlieten om naar MAVO/HAVO/VWO (63,7\%), LBO $(33,0 \%)$ of $\mathrm{MBO}(0,4 \%)$ te gaan. De overige personen namen niet meer deel aan vervolgonderwijs $(2,9 \%)$.

Op deze manier worden ook de stromen van het vervolgonderwijs in kaart gebracht. In het vervolgonderwijs is er echter naast de gediplomeerde uitstroom ook de mogelijkheid om het onderwijs ongediplomeerd te verlaten en vervolgens een andere opleiding te gaan doen (zie tabel 2.2). Het "Overig Deeltijd" onderwijs is bij de uitstroom geteld omdat dit onderwijs in de prognosemethodiek ook niet bij het initiële onderwijs wordt gerekend. Schoolverlaters van de beroepsbegeleidende leerweg (BBL) zijn bij het MBO geteld.

Zoals blijkt uit tabel 2.2 moeten er aannames worden gemaakt over het jaar waarin men het onderwijs met of zonder diploma verlaat. Voor het MAVO is ervoor gekozen om aan de gediplomeerden een gemiddelde verblijfsduur van 4 jaar toe te kennen, hetgeen gelijk is aan de nominale duur van de opleiding, en aan de ongediplomeerden een gemiddelde verblijfsduur van 2 jaar. Dit laatste omdat uit de onderwijsmatrix van $1991^{7}$ blijkt dat $70 \%$ van de ongediplomeerden MAVO binnen 2 jaar verlaat. Voor de overige opleidingsniveaus is gekozen voor een even lange verblijfsduur voor de gediplomeerden als de ongediplomeerden. ${ }^{8}$ Deze keuzes zijn gemaakt op basis van CBS-schattingen over de verblijfsduur in het onderwijs van gediplomeerden en de schoolverlatersgegevens van het ROA.

7. Vanaf 1991 zijn de onderwijsmatrices meer gespecificeerd.

8. Voor LBO 4 jaar, HAVO/VWO 6 jaar, MBO en HBO 4 jaar en WO 5 jaar.

4 
Tabel 2.2

Onderwijsstromen: MAVO naar vervolgonderwijs/uitstroom

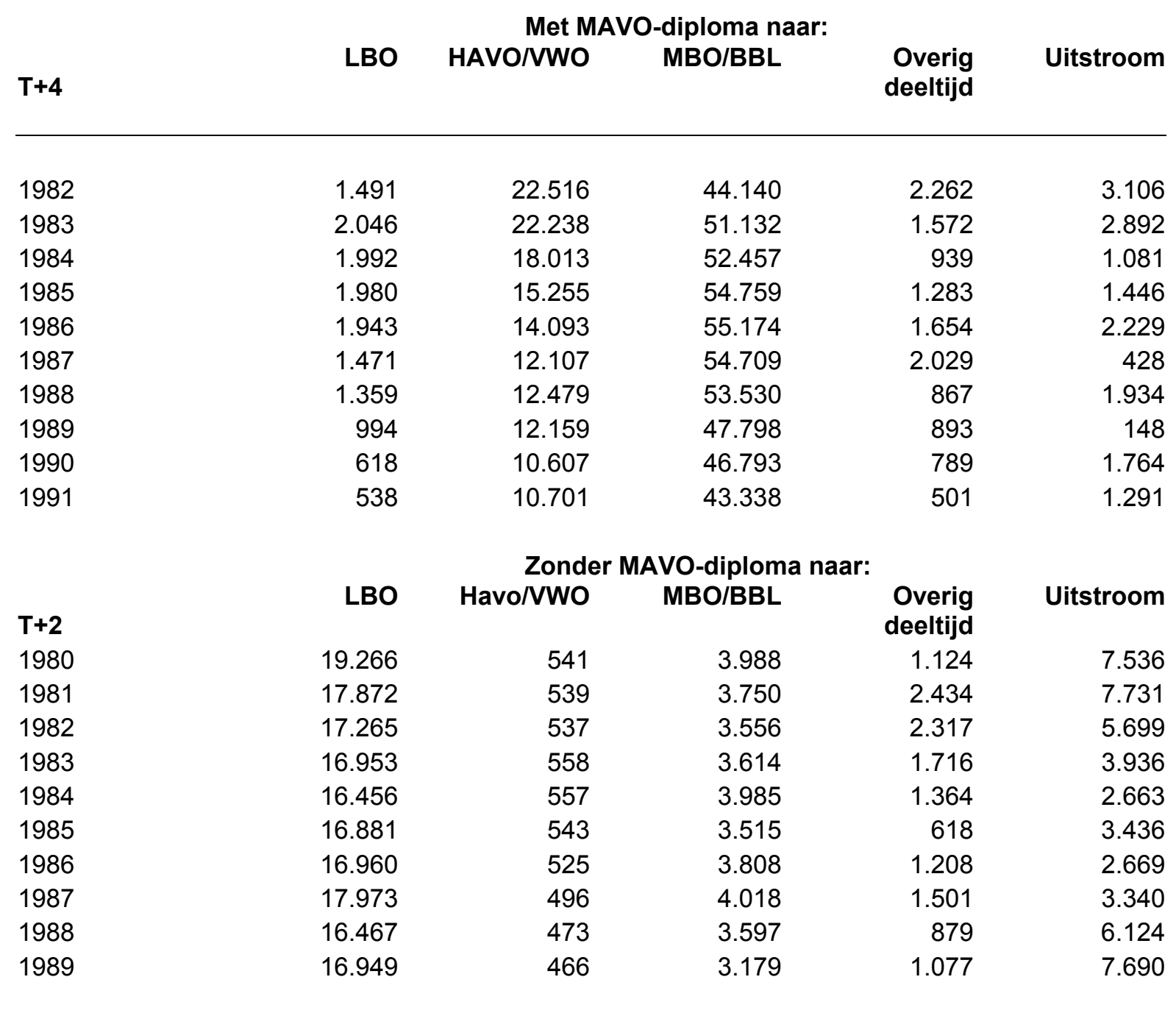

Bron: CBS, Onderwijsmatrices 1980 t/m 1991

Uit tabel 2.2 blijkt dat er vier mogelijke stromen te onderscheiden zijn: (1) Men stroomt gediplomeerd uit het onderwijs, (2) men stroomt ongediplomeerd uit het onderwijs, (3) men gaat met diploma aan vervolgonderwijs deelnemen of (4) men gaat zonder diploma vervolgonderwijs volgen. De uitstroom van ongediplomeerden vormt samen met de uitstroom van gediplomeerden de absolute bovengrens van het aantal schoolverlaters. Echter, de uitstroom van gediplomeerden wordt rechtstreeks toegekend aan het uiteindelijk behaalde diploma en de uitstroom van ongediplomeerden wordt herverdeeld naar gediplomeerde vooropleiding.

Deze verdeling vindt plaats door de gediplomeerde en ongediplomeerde doorstroom in het vervolgonderwijs te beschouwen als de vooropleiding van de ongediplomeerde uitstroom. Dit kan alleen kloppen indien de instroomverdeling in een opleiding naar vooropleiding dezelfde is voor gediplomeerden als voor ongediplomeerden. In appendix A wordt met het Schoolverlaters Informatie Systeem aangetoond dat dit het geval is. 
Tabel 2.3

Instroom in het LBO vanuit ongediplomeerde en gediplomeerde vooropleiding

Bron: Onderwijsmatrices, CBS

\section{De reconstructie vergeleken met de $\mathrm{EBB}^{9}$}

De eindresultaten van de reconstructie worden verkregen door de gediplomeerde en de herleide ongediplomeerde schoolverlaters bij elkaar op te tellen. Uit tabel B.2 (Appendix B) blijkt dat het verschil tussen begin- en eindaantal voor de cohort 30-34 jarigen zo'n 68.000 personen is. Voor de cohort 25-29 jarigen is dit verschil kleiner, namelijk 24.000 personen. Opvallend is dat er bij de eerste groep te weinig mensen uit het stroomsysteem stromen, terwijl het er bij de tweede groep te veel zijn. Ook is opvallend dat de beginaantallen van vooral de 30-34 jarigen afwijken van de EBB-cijfers. Wat betreft de totaalaantallen blijken de resultaten van de cohort 25 tot en met 29- jarigen goed overeen te komen met de cijfers uit de Enquête Beroepsbevolking. Deze verschillen kunnen met zowel veronderstellingen in de methodiek (bijvoorbeeld studieduur) als met migratie en sterfte te maken hebben.

De resultaten worden in tabel B.3 gecorrigeerd voor de instroom in het onderwijs na een afwezigheid van korte of langere duur. Deze correctie vindt plaats door de instroom in het onderwijs van degenen die in de voorafgaande telling niet in het voltijdonderwijs zaten, op te splitsen met behulp van tot nog toe in de prognoses ongebruikte gegevens: de terugstroom van ongediplomeerden in het voltijdonderwijs (ook wel genoemd: indirecte instroom in het onderwijs). De ongediplomeerden die met enige onderbreking terugstromen in het initiële onderwijs, kunnen vervolgens gediplomeerd of ongediplomeerd het onderwijs weer uitstromen. Volgens gegevens van het Ministerie van OCenW bestaat de terugstroom in het voltijd Beroepsopleidende Leerweg (BOL) jaarlijks uit 11.000 ongediplomeerden. In het voltijd-HBO gaat het om 15.000 ongediplomeerden en in het voltijd-WO 8.000 ongediplomeerden die terugstromen in het onderwijs na een onderbreking van hun onderwijsloopbaan. De gegevens over de vooropleidingen zijn beperkt, evenals de gegevens over het diplomarendement. In de analyse wordt daarom aangenomen dat men

9. Omdat de EBB de grootste steekproef heeft (1\% van de Nederlandse bevolking) ten opzichte van andere bronnen, zullen de cijfers uit de reconstructie naar opleidingsniveau vergeleken worden met de gegevens uit de EBB. In appendix B (tabel B.1) staan ter vergelijking de gegevens naar opleidingsniveau uit het SEP en het OSA aanbodpanel. 
dezelfde opleidingsachtergrond en rendementen ${ }^{10}$ heeft als de directe instroom in het onderwijs.

De correctie heeft een grote invloed op het eindresultaat. Zo studeren bijvoorbeeld 35.700 ongediplomeerden van het HBO die in het jaar 200030 tot en met 34 jaar oud waren en een HAVO/NWO-vooropleiding hadden, door aan het HBO na een korte of langere tijd uit het onderwijssysteem te zijn geweest. In totaal blijkt voor de 30 tot en met 34 jarigen $33 \%$ van de HAVO/VWO-ongediplomeerden na een bepaalde tijd weer te gaan deelnemen aan het initiële onderwijs. Voor MBO en HBO zijn deze percentages kleiner maar nog altijd substantieel, respectievelijk $5 \%$ en $2 \%$. Door de terugstroom stijgen de rendementen in het MBO, HBO en WO aanzienlijk (zie tabel C.2).

Tabel 3.1

Vergelijking tussen de reconstructie en de EBB van de verdeling naar opleidingsniveau

\begin{tabular}{|c|c|c|c|c|c|}
\hline $\begin{array}{l}\text { Leeftijd } \\
\text { in } 2000\end{array}$ & Beginaantal & $\begin{array}{l}\text { Uiteindelijke } \\
\text { diploma }\end{array}$ & Eindaantal & Reconstructie & $\begin{array}{r}\text { EBB } \\
\%\end{array}$ \\
\hline \multirow[t]{7}{*}{ 30-34 jaar } & & $\mathrm{BAO}$ & 165.327 & 15,6 & 8,0 \\
\hline & & VMBO & 229.887 & 21,8 & 19,1 \\
\hline & & HAVO/VWO & 127.822 & 12,1 & 6,2 \\
\hline & & MBO & 292.582 & 27,7 & 38,8 \\
\hline & & $\mathrm{HBO}$ & 135.006 & 12,8 & 17,8 \\
\hline & & WO & 106.106 & 10,0 & 10,2 \\
\hline & 1.239 .727 & Totaal & 1.056 .729 & 100 & 100 \\
\hline \multirow[t]{7}{*}{ 25-29 jaar } & & $\mathrm{BAO}$ & 168.930 & 16,8 & 7,8 \\
\hline & & VMBO & 177.997 & 17,8 & 16,9 \\
\hline & & HAVO/VWO & 107.573 & 10,7 & 6,5 \\
\hline & & MBO & 249.726 & 24,9 & 38,4 \\
\hline & & $\mathrm{HBO}$ & 180.630 & 18,0 & 20,3 \\
\hline & & WO & 117.850 & 11,8 & 9,9 \\
\hline & 1.094.191 & Totaal & 1.002 .705 & 100 & 100 \\
\hline
\end{tabular}

Bron: CBS (EBB 2000)

Tabel 3.1 laat de eindresultaten inclusief de correctie voor de terugstroom van ongediplomeerden in het onderwijs zien. De berekening van het totale aantal schoolverlaters valt lager uit door deze correctie. Dit komt doordat het berekende aantal ongediplomeerde schoolverlaters daalt, terwijl het aantal gediplomeerde schoolverlaters constant blijft. Hierbij wordt ervan uitgegaan dat de terugstroom in het onderwijs leidt tot minder ongediplomeerden. Er wordt immers aangenomen dat de registratie van gediplomeerden goed verloopt, terwijl het aantal ongediplomeerden overschat wordt. Het blijkt zoals verwacht dat de verdeling wat beter overeenkomt met de verdeling volgens de EBB. Echter, de voortijdige schooluitval blijft zeer hoog. Het verschil tussen de resultaten van de reconstructie en de

10. Voor een overzicht van de rendementen berekend in de reconstructie, zie tabel C. 1 
EBB verdeling kan liggen aan de aannames in de reconstructie (bijvoorbeeld met betrekking tot de studieduur) maar ook aan het feit dat in de EBB schoolverlaters van het postinitiële onderwijs zijn meegeteld terwijl de reconstructie de resultaten van schoolverlaters van het initiële voltijdonderwijs laat zien.

\section{De instroomprognoses vergeleken met de referentieraming en de EBB}

De implicaties van de bovenstaande bevindingen over de terugstroom van ongediplomeerden in het onderwijs worden in deze paragraaf toegepast op de prognoses. Om een goed beeld te geven van de prognoses zullen deze eerst stap voor stap worden weergegeven. Omdat de prognoses betrekking hebben op verschillende leeftijdscohorten is gekozen voor een vergelijking met gegevens van het Ministerie van OCenW, naast de eerder gebruikte EBB-gegevens over de leeftijdscohorten.

In tabel 4.1 zijn de basisprognoses over de gediplomeerde schoolverlaters weergegeven. Ter controle zijn deze prognoses vergeleken met de gegevens uit de Referentieraming van het Ministerie van OCenW. Uit de Referentieraming zijn voor de vergelijking in de tabel de prognosegegevens afgeleid. De gegevens blijken zoals verwacht zowel qua totaal aantal schoolverlaters en afgestudeerden als qua verdeling zeer goed overeen te komen.

Tabel 4.1

Vergelijking van het aantal gediplomeerde schoolverlaters uit het initieel voltijdonderwijs (excl. $B B L$ ), prognoses ROA en OCenW, 2001-2006

\section{Basisonderwijs}

VMBO

HAVO/VWO

$\mathrm{MBO}$

$\mathrm{HBO}$

WO

Totaal
41.440

101.010

9.713

202.668

199.430

92.593

647.500
41.601

101.235

9.679

202.740

199.509

92.509

647.273

Bron: ROA (Project Onderwijs-arbeidsmarkt) 2001; Ministerie van OCenW (Referentieraming)

Vervolgens wordt de arbeidsmarktinstroom van de ongediplomeerde schoolverlaters nadat deze herrekend zijn naar hun hoogst voltooide vooropleiding, bij de instroom van gediplomeerde schoolverlaters op de arbeidsmarkt opgeteld. Uit tabel 4.2 blijkt zoals verwacht dat de verdeling van schoolverlaters na deze bewerking verschuift van de hogere opleidingsniveaus naar de lagere. Immers, ongediplomeerde schoolverlaters hebben bijna altijd een lagere vooropleiding. Uit de vergelijking met tabel 4.1 kan worden afgeleid dat het 
grootste gedeelte van de HAVO/VWO-schoolverlaters uit het initiële onderwijs voortijdig schoolverlater is. Uit de tabel is af te leiden dat het aantal schoolverlaters met een laag opleidingsniveau erg hoog is ten opzichte van de verdeling naar opleidingsniveau van de twee vijfjaarscohorten van de EBB zoals weergegeven in de vorige paragraaf. Dit zou mede kunnen komen doordat er nog geen rekening is gehouden met het volgen van een niveauverhogende opleiding in het deeltijdonderwijs en het postinitieel onderwijs.

Naast de ROA-prognoses zijn de beschikbare gegevens uit de Referentieraming weergegeven. Helaas is alleen het totaal van gediplomeerde en ongediplomeerde schoolverlaters beschikbaar omdat de ongediplomeerde schoolverlaters niet worden teruggerekend in de Referentieraming. Het totaal aantal schoolverlaters van de ROA-prognoses en de Referentieraming blijkt zeer goed overeen te komen. Deze prognoses zijn daarentegen erg hoog vergeleken met het aantal schoolverlaters volgens de EBB. Volgens de EBB waren er in het jaar 2000197.819 schoolverlaters en afgestudeerden. Over een periode van vijf jaar bedraagt dit aantal 989.095, dat wil zeggen ongeveer 100.000 minder dan volgens de ROAen OCenW-prognoses. Uit de leeftijdsopbouw van de bevolking blijkt echter dat er in de komende vijf jaar eerder een daling dan een stabilisatie van het aantal schoolverlaters en afgestudeerden is te verwachten. Daarom zouden de prognoses eerder lager dan hoger dan de EBB-cijfers moeten uitkomen.

Tabel 4.2

Vergelijking van het aantal gediplomeerde en ongediplomeerde schoolverlaters uit het initieel voltijdonderwijs (excl. BBL), prognoses ROA en Referentieraming, 2001-2006

$\begin{array}{rrr}\text { Arbeidsmarktinstroom ROA } & \text { Verdeling } \mathrm{ROA} & \text { Arbeidsmarktinstroom } \\ \% & \text { OCenW }\end{array}$

$\begin{array}{lrrr}\text { Basisonderwijs } & 134.601 & 12,2 & \\ \text { VMBO } & 289.210 & 26,3 & \\ \text { HAVO/VWO } & 133.284 & 12,1 & \\ \text { MBO } & 228.603 & 20,8 & \\ \text { HBO } & 214.430 & 19,5 & 1.087 .894 \\ \text { WO } & 99.828 & 9,1 & \\ \text { Totaal } & 1.099 .957 & 100 & \end{array}$

Bron: ROA (Project Onderwijs-arbeidsmarkt), 2001; Ministerie van OCenW (Referentieraming)

Vervolgens wordt berekend hoe de samenstelling verandert indien rekening wordt gehouden met schoolverlaters uit de beroepsbegeleidende leerweg (BBL, het vroegere leerlingwezen). Hoewel deze onderwijsvorm tegenwoordig als regulier onderwijs wordt beschouwd, wordt de arbeidsmarktinstroom van BBL-gediplomeerden in de prognosemethodiek in een aparte stap berekend omdat de BBL (1) in de referentieraming bij het deeltijdonderwijs wordt gerekend en (2) de BBL een ander karakter heeft dan de beroepsopleidende leerweg (BOL) in het initiële onderwijs. In de prognosemethodiek worden degenen die participeren in de BBL meestal als werkend beschouwd. Dit heeft als consequentie dat in tegenstelling tot de correctie in het initiële onderwijs voor de doorstroom van de ene initiële opleiding naar de 
andere, de doorstroom naar de BBL als arbeidsmarktinstroom wordt beschouwd. Dit leidt bij het afsluiten van de BBL-opleiding tot een dubbeltelling in de instroomprognoses. Hiervoor wordt in de vervangingsvraagprognoses gecorrigeerd, omdat er in de ROA-methodiek (zie Cörvers, et al., 2002) vervangingsvraag ontstaat naar personen met de vooropleiding van werkenden die het BBL-diploma behalen. Voor de analyses in dit werkdocument is, in tegenstelling tot de normale ROA-methodiek voor de instroomprognoses, wel gecorrigeerd voor de vooropleiding van schoolverlaters van de BBL om een beeld te krijgen van de netto arbeidsmarktinstroom van schoolverlaters. Onder netto arbeidsmarktinstroom wordt de uitstroom uit het onderwijs minus de instroom in het onderwijs verstaan.

De gegevens na correctie voor de beroepsbegeleidende leerweg worden in tabel 4.3 vergeleken met de cijfers van het ministerie van Onderwijs, Cultuur en Wetenschappen (enkele resultaten van deze berekeningen van het ministerie zijn op een hoger aggregatieniveau weergegeven in Kerncijfers (2001)). In de eerste plaats zijn de totaal aantallen uit de ROA-prognoses hoger (ter vergelijking moeten de cijfers van OCenW vermenigvuldigd worden met vijf). Daarnaast blijkt er een verschil in de verdeling van de schoolverlaters over de opleidingsniveaus te bestaan. In de cijfers van OCenW zijn er meer hoger opgeleiden (hoger dan MBO). Dit uit zich vooral in een verschil tussen de HAVO/VWO cijfers (hoger in de prognoses) en de HBO/WO cijfers (lager in de prognoses). Dit verschil heeft een aantal oorzaken. In de eerste plaats is er nog geen rekening gehouden met een derde deel van de deeltijd-gediplomeerden (ongeveer 20.000 schoolverlaters per jaar, dus voor de prognoseperiode 100.000 schoolverlaters). Met deze schoolverlaters wordt in de prognosemethodiek van het ROA rekening gehouden bij de prognoses van het postinitiële onderwijs. Daarnaast is er in tabel 4.3 bij de methodiek van OCenW, in tegenstelling tot de gegevens van OCenW in tabel 4.2, rekening gehouden met de terugstroom in het onderwijs waarop in de voorgaande paragraaf over de reconstructie van onderwijsloopbanen werd gewezen. Hierdoor valt het het aantal schoolverlaters en afgestudeerden substantieel lager uit.

Tabel 4.3

Afleiding van de netto arbeidsmarktinstroom van gediplomeerden van het initieel voltijdonderwijs (incl. BBL), prognoses ROA en OCenW, 2001-2006

\begin{tabular}{|c|c|c|c|c|c|c|c|c|}
\hline & $\begin{array}{r}\text { Bruto } \\
\text { instroom } \\
\text { aantal }\end{array}$ & $\begin{array}{c}\text { BBL } \\
\text { aantal }\end{array}$ & $\begin{array}{r}\text { Voor- } \\
\text { opleiding } \\
\text { aantal }\end{array}$ & $\begin{array}{r}\text { Netto } \\
\text { instroom } \\
\text { aantal }\end{array}$ & $\begin{array}{r}\mathrm{ROA} \\
\text { verdeling } \\
\text { tot } 2006 \\
\%\end{array}$ & $\begin{array}{r}\text { OC\&W } \\
\text { verdeling } \\
1990 \\
\%\end{array}$ & $\begin{array}{r}\text { OC\&W } \\
\text { verdeling } \\
2000 \\
\%\end{array}$ & $\begin{array}{r}\text { OC\&W } \\
\text { verdeling } \\
2010 \\
\%\end{array}$ \\
\hline $\begin{array}{l}\text { Basis- } \\
\text { onderwijs }\end{array}$ & 134.601 & 0 & 24.008 & 110.593 & 10,1 & 7,9 & 8,6 & 7,5 \\
\hline VMBO & 289.210 & 15.013 & 113.943 & 190.280 & 17,3 & 29,9 & 14,2 & 18,9 \\
\hline $\begin{array}{l}\text { HAVO/ } \\
\text { VWO }\end{array}$ & 133.284 & 0 & 13.009 & 120.275 & 10,9 & 4,9 & 4,8 & 5,6 \\
\hline MBO & 228.603 & 154.656 & 18.716 & 364.543 & 33,1 & 32,3 & 33,6 & 30,5 \\
\hline $\mathrm{HBO}$ & 214.430 & 0 & 0 & 214.430 & 19,5 & 15,5 & 26,1 & 25,7 \\
\hline \multirow[t]{2}{*}{ WO } & 99.828 & 0 & 0 & 99.828 & 9,1 & 9,5 & 12,7 & 11,8 \\
\hline & & & & & 100 & 100 & 100 & 100 \\
\hline Totaal & 1.099 .957 & 169.669 & 169.676 & 1.099 .957 & 1.099 .957 & 189.000 & 157.000 & 172.000 \\
\hline
\end{tabular}


Wat betreft de arbeidsmarktinstroom van gediplomeerde schoolverlaters met een HAVO/VWO-diploma als hoogst behaalde opleiding zijn volgens tabel 4.3 de ROAprognoses voor het initiële voltijdonderwijs (inclusief BBL) duidelijk hoger in vergelijking met de OCenW-prognoses. In tabel 4.4 wordt inzichtelijk gemaakt wat er met de verdeling gebeurt indien er gecorrigeerd wordt voor de terugstroom in het onderwijs van ongediplomeerden, zoals eerder uitgevoerd in de reconstructie-analyse. De invloed van de correctie is groot. Ten eerste daalt het totaal aantal schoolverlaters met ongeveer $10 \%$. Dit aantal komt beter overeen met de gegevens van het Ministerie van OCenW en vooral ook met gegevens uit de EBB. Ten tweede wordt door de correctie de arbeidsmarktinstroom van schoolverlaters met een HAVO/VWO-diploma gehalveerd, terwijl de arbeidsmarktinstroom van het VMBO ook daalt. Daarentegen stijgt het aantal afgestudeerden van het MBO, HBO en WO. De verdeling naar opleidingsniveau blijkt zeer goed overeen te komen met de prognoses van het Ministerie van OCenW en de EBB. Uitzondering hierop is het grotere aantal personen met uitsluitend een opleiding van de basisschool (de ongeschoolden), hoewel het verschil niet groot is. Geconcludeerd kan worden dat de terugstroom in het onderwijs een onontbeerlijke correctie is die bij het samenstellen van de prognoses tot 2008 niet mag ontbreken.

Tabel 4.4

Arbeidsmarktinstroom tot 2006 (initieel voltijdonderwijs en BBL) na correctie met de ongediplomeerde terugstroom in het onderwijs, vergelijking met gegevens van OCenW en EBB

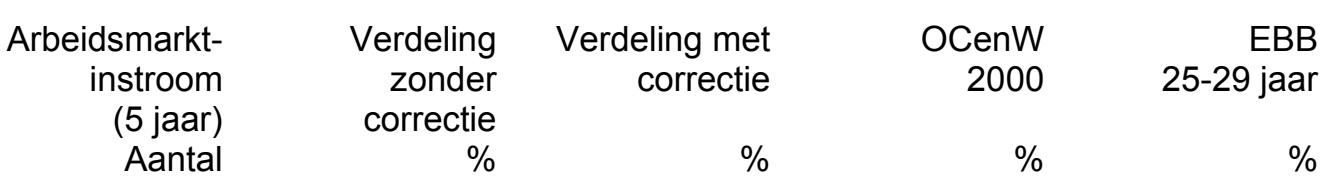

\begin{tabular}{lrrrrr}
\hline & & & & & \\
BAO & 110.593 & 10,1 & 11,2 & 8,6 & 7,8 \\
VMBO & 156.620 & 17,3 & 15,9 & 14,2 & 16,9 \\
HAVO/VWO & 56.715 & 10,9 & 5,8 & 4,8 & 6,5 \\
MBO & 349.243 & 33,1 & 35,5 & 33,6 & 38,4 \\
HBO & 211.750 & 19,5 & 21,5 & 26,1 & 20,3 \\
WO & 99.828 & 9,1 & 10,1 & 12,7 & 9,9 \\
Totaal & 984.749 & 100 & 100 & 100 & 100
\end{tabular}

Bron: ROA (Project Onderwijs-arbeidsmarkt), 2001; Ministerie van OCenW (2001); CBS (EBB 2000)

\section{Samenvatting}

Uit de Arbeidsmarkt naar opleiding en beroep tot 2006 blijkt dat de verwachte arbeidsmarktinstroom van met name het opleidingstype HAVO/NWO erg hoog is ten opzichte van de opleidingsachtergrond van vijfjaarscohorten van de Enquête Beroepsbevolking (EBB) van het CBS. Volgens de berekeningen van het ROA bestaat deze instroom voor het grootste gedeelte uit voortijdig schoolverlaters van het $\mathrm{HBO}$ en het WO aan wie HAVO/VWO als hoogst voltooide opleiding wordt toegeschreven. Dit grote aantal schoolverlaters was de aanleiding voor het onderzoek naar de prognosemethodiek van de 
instroom op de arbeidsmarkt van opleidingen binnen het initiële onderwijs. In het onderzoek zijn het initiële voltijdonderwijs en de opleidingen in het kader van de beroepsbegeleidende leerweg (BBL) betrokken. De instroom op de arbeidsmarkt van leerlingen en studenten die een deeltijdopleiding of postinitiële opleiding afsluiten blijft hierbij buiten beschouwing. Hetzelfde geldt voor werkenden die van opleidingsachtergrond veranderen. ${ }^{11}$

In de Arbeidsmarkt naar opleiding en beroep tot 2006 wordt de schooluitval bepaald op grond van het geprognostiseerde aantal ongediplomeerde schoolverlaters en afgestudeerden uit de Referentieraming. In dit werkdocument is met behulp van de onderwijsmatrices van het CBS per leeftijdscohort nagegaan met welk opleidingsniveau men uiteindelijk instroomt op de arbeidsmarkt. In plaats van prognoses te maken wordt op deze wijze met dezelfde methodiek als voor de prognoses de verdeling naar opleidingsniveau voor twee leeftijdscohorten berekend. Het blijkt dat het totale aantal schoolverlaters en afgestudeerden uit de reconstructie van leeftijdscohorten goed overeenkomt met de EBBgegevens voor het de leeftijdscohort 25 tot en met 29 jaar, maar minder goed met de EBBgegevens voor het de leeftijdscohort 30 tot en met 34 jaar. De verschillen kunnen te maken hebben met de aannames in de reconstructie (met betrekking tot studieduur), met sterfte of migratie. De verdeling van schoolverlaters en afgestudeerden naar opleidingsniveau voor de twee leeftijdscohorten blijkt op een aantal punten aanzienlijk af te wijken van de verdeling volgens de EBB. Dit heeft mogelijk te maken met de relatief grote voortijdige schooluitval in de reconstructie.

Door een nadere bestudering van de systematiek van de onderwijsmatrix wordt vastgesteld dat bepaalde personen onterecht als schoolverlater worden aangemerkt. Deze personen blijken na korte of langere tijd het onderwijssysteem te hebben verlaten, weer terug te stromen in het onderwijs. Dit heeft als consequentie dat het aantal ongediplomeerde schoolverlaters wordt overschat. Door de rendementen en de vooropleidingen van de oorspronkelijke reconstructie-analyse toe te passen op de terugstroom in het onderwijs, en de verdeling naar opleidingsniveau per leeftijdscohorten opnieuw te berekenen, blijkt voor HAVO/NWO de grootste overschatting van instroom op de arbeidsmarkt te bestaan. Ongeveer een derde deel van de schoolverlaters met HAVO/VWO als hoogst voltooide vooropleiding gaat later weer met succes een opleiding volgen. De correctie voor de terugstroom van ongediplomeerden in het onderwijs verhoogt de impliciete rendementen van leerlingen en studenten van het $\mathrm{MBO}, \mathrm{HBO}$ en WO gemiddeld met respectievelijk 2 procent, 6 procent en 5 procent (zie appendix C).

Door de correctie op de prognoses toe te passen blijken zowel het totaal als de verdeling van de opleidingsniveaus beter overeen te komen met andere beschikbare bronnen, waaronder de gegevens van het Ministerie van OCenW en de EBB. De correctie met de terugstroom in het onderwijs zal daarom worden toegepast in de prognosemethodiek.

11. Voor de methodiek met betrekking tot de arbeidsmarktinstroom vanuit het deeltijdonderwijs en het niet-initiële onderwijs wordt verwezen naar De Grip en Jacobs (1999) en Cörvers et al. (2002). 


\section{Literatuur}

Allen, J., T. Huijgen en R. Welters (2001), Pilotstudie voortijdig schoolverlaters 1995/1996, ROA-W2001/4, Maastricht.

Cörvers, F., B.J. Diephuis, S. Dijksman, B. Golsteyn, M. Hensen, Ph. Marey (2002), Methodiek arbeidsmarktprognoses en -indicatoren 2001-2006, ROA-W-2002/4, Maastricht.

Grip, A. de en A. Jacobs (1999), De doorstroom van het initieel naar het niet-initieel onderwijs, ROAW-1999/3, Maastricht.

Ministerie van Onderwijs, Cultuur en Wetenschappen (2001), Onderwijs Cultuur en Wetenschappen in kernciffers, Zoetermeer.

Ministerie van Onderwijs, Cultuur en Wetenschappen (2002), Referentieraming 2002, Zoetermeer.

ROA (2001), De arbeidsmarkt naar opleiding en beroep tot 2006, ROA-R-2001/8, Maastricht. 


\section{Appendix A}

Een cruciale veronderstelling in de prognosemethodiek is dat de instroomverdeling in een opleiding naar vooropleiding hetzelfde is voor gediplomeerde als voor ongediplomeerde schoolverlaters. Immers, om de vooropleiding van een ongediplomeerde te berekenen wordt de instroomverdeling van alle personen in een opleiding als uitstroomverdeling genomen. Als blijkt dat personen met een bepaalde vooropleiding een grotere kans hebben om te slagen, is deze veronderstelling verkeerd en wordt de vooropleiding foutief berekend.

In het SchoolverlatersInformatieSysteem (SIS) wordt anderhalf jaar na het verlaten van de opleiding aan de gediplomeerden gevraagd of zij een vervolgopleiding zijn gaan doen en of zij hier nog mee bezig zijn. Onder de veronderstelling dat degenen die nog bezig zijn de opleiding deze ook daadwerkelijk zullen afmaken, toont tabel A.1 de verdeling van de vooropleiding van gediplomeerde en ongediplomeerde MBO-, HBO- en WO-studenten.

Tabel A.1

Vooropleiding MBO-, HBO-, WO-gediplomeerden en -ongediplomeerden

\begin{tabular}{|c|c|c|c|c|}
\hline & & $\begin{array}{r}\text { Volgt opleiding } \\
\text { nog } \\
\text { (=gediplomeerd) } \\
\%\end{array}$ & $\begin{array}{r}\text { Opleiding reeds } \\
\text { verlaten } \\
\text { (=ongediplomeerd) } \\
\%\end{array}$ & $\begin{array}{r}\text { Totaal } \\
\%\end{array}$ \\
\hline \multirow{5}{*}{ MBO } & VMBO & 78,1 & 80,9 & 78,4 \\
\hline & HAVO/VWO & 7,0 & 5,6 & 6,8 \\
\hline & MBO & 14,9 & 13,5 & 14,7 \\
\hline & Totaal & 100 & 100 & 100 \\
\hline & Aantal & 409.268 & 54.552 & 463.820 \\
\hline \multirow[t]{7}{*}{$\mathrm{HBO}$} & VMBO & 0,4 & 0,2 & 0,4 \\
\hline & HAVO/VWO & 61,0 & 63,5 & 61,4 \\
\hline & $\mathrm{MBO}$ & 31,5 & 32,1 & 31,6 \\
\hline & $\mathrm{HBO}$ & 6,9 & 4,1 & 6,5 \\
\hline & WO & 0,3 & 0,1 & 0,2 \\
\hline & Totaal & 100 & 100 & 100 \\
\hline & Aantal & 256.578 & 44.333 & 300.911 \\
\hline \multirow[t]{7}{*}{ WO } & VMBO & 0,1 & 0,0 & 0,1 \\
\hline & HAVO/VWO & 71,0 & 74,3 & 71,4 \\
\hline & MBO & 0,2 & 0,2 & 0,2 \\
\hline & $\mathrm{HBO}$ & 26,2 & 23,4 & 25,8 \\
\hline & WO & 2,5 & 2,1 & 2,5 \\
\hline & Totaal & 100 & 100 & 100 \\
\hline & Aantal & 117.559 & 17.446 & 135.005 \\
\hline
\end{tabular}

Bron: SIS (ROA), 1996-2001

Uit de tabel blijkt bijvoorbeeld dat $78,4 \%$ van alle personen die MBO hebben geprobeerd, een VMBO-achtergrond hadden. Van de personen die het MBO afsluiten met een diploma, heeft $78,1 \%$ een VMBO-vooropleiding. Van de personen die het MBO zonder diploma beëindigen heeft $80,9 \%$ een VMBO-vooropleiding. Dergelijk kleine verschillen tussen de 
vooropleiding van de gediplomeerden en de ongediplomeerden blijken voor alle vooropleidingen te gelden.

Uit de tabel kan worden geconcludeerd dat de verschillen in de verdeling tussen gediplomeerden en ongediplomeerden dusdanig klein zijn dat de veronderstelling dat ongediplomeerden volgens dezelfde verdeling van vooropleiding het onderwijs instromen als de gediplomeerden, kan worden gehandhaafd. 


\section{Appendix B}

Tabel B. 1

Verdeling naar hoogst voltooide onderwijsniveau volgens Sociaal Economisch Panel (SEP) en OSA aanbodpanel ${ }^{12}$

SEP

OSA

25-29 jaar

30-35 jaar

35-40 jaar

$>=25$ jaar

$\%$

$\%$

$\%$

$\begin{array}{lrrrr}\text { Basisonderwijs } & 3,8 & 3,3 & 6,1 & 5,6 \\ \text { VMBO } & 12,9 & 17,3 & 16,7 & 34,7 \\ \text { HAVO/VWO } & 4,5 & 5,0 & 4,9 & 8,4 \\ \text { MBO } & 43,7 & 48,4 & 45,0 & 23,6 \\ \text { HBO } & 23,8 & 17,8 & 20,6 & 20,2 \\ \text { WO } & 11,3 & 8,1 & 6,7 & 7,3 \\ \text { Totaal } & 100 & 100 & 100 & 100 \\ \text { Aantal } & 800 & 900 & 1000 & 4000\end{array}$

Bron: Sociaal Economisch Panel, 1998 en OSA aanbodpanel, 2000

Tabel B. 2

Resultaten van de reconstructie van onderwijsloopbanen, exclusief de terugstroom van ongediplomeerden in het onderwijs, en de vergelijking met de EBB

\begin{tabular}{|c|c|c|c|c|c|}
\hline $\begin{array}{l}\text { Leeftijd in } \\
2000\end{array}$ & Beginaantal & $\begin{array}{l}\text { Uiteindelijke } \\
\text { diploma }\end{array}$ & aantal & $\begin{array}{r}\text { Reconstructie } \\
\%\end{array}$ & $\begin{array}{r}\text { EBB } \\
\%\end{array}$ \\
\hline \multirow[t]{7}{*}{ 30-34 jaar } & & BAO & 165.327 & 14,1 & 8,0 \\
\hline & & VMBO & 263.547 & 22,5 & 19,1 \\
\hline & & HAVO/VWO & 191.382 & 16,3 & 6,2 \\
\hline & & MBO & 307.882 & 26,3 & 38,8 \\
\hline & & $\mathrm{HBO}$ & 137.686 & 11,7 & 17,8 \\
\hline & & wo & 106.106 & 9,1 & 10,2 \\
\hline & 1.239 .727 & Totaal & 1.171 .929 & 100 & 100 \\
\hline \multirow[t]{7}{*}{ 25-29 jaar } & & $\mathrm{BAO}$ & 168.930 & 15,1 & 7,8 \\
\hline & & VMBO & 211.657 & 18,9 & 16,9 \\
\hline & & HAVO/VWO & 171.133 & 15,3 & 6,5 \\
\hline & & $\mathrm{MBO}$ & 265.026 & 23,7 & 38,4 \\
\hline & & HBO & 183.310 & 16,4 & 20,3 \\
\hline & & WO & 117.850 & 10,5 & 9,9 \\
\hline & 1.094 .191 & Totaal & 1.117 .905 & 100 & 100 \\
\hline
\end{tabular}

12. Wegens de kleine steekproef is bij het OSA aanbodpanel geen opsplitsing gemaakt naar 3 cohorten. 
Tabel B.3

Correctie van de reconstructie van onderwijsloopbanen met de terugstroom in het onderwijs

$\begin{array}{rrrr}\text { aantal } & \text { terugstroom in het onderwijs } & \text { arbeidsmarkt- } \\ \text { gediplomeerden } & \text { naar } & \text { aantal } & \text { instroom }\end{array}$

30-34 jaar

BAO

VMBO

HAVO/VWO

$\mathrm{HBO}$

WO

25-29 jaar

BAO

VMBO

HAVO/VWO

MBO

$\mathrm{HBO}$

WO
165.327

263.547

191.382

totaal

MBO

$\mathrm{HBO}$

WO

307.882

137.686

106.106

HBO

WO

168.930

211.657

171.133

totaal

MBO

$\mathrm{HBO}$

WO

265.026

183.310

117.850
165.327

229.887

33.660

127.822

3.740

35.700

24.120

15.300

292.582

2.680

135.006

106.106

168.930

177.997

33.660

63560

107.573

3.740

35.700

24.120

15.300

249.726

WO 2.680

180.630

117.850 


\section{Appendix C}

Tabel C.1

Impliciete rendementen in de reconstructie-analyse

\begin{tabular}{lrrrrrrr} 
& $\%$ & $\%$ & $\%$ & $\begin{array}{r}\% \\
\text { HAVO/ } \\
\text { VWO }\end{array}$ & MBO & HBO & WO \\
Leeftijd in 2000 & BAO & LBO & MAVO & & & & \\
\hline 34 & 100 & 83,3 & 69,4 & 81,2 & 65,5 & 63,8 & 79,3 \\
33 & 100 & 84,4 & 71,2 & 81,0 & 67,7 & 61,1 & 69,6 \\
32 & 100 & 84,1 & 71,7 & 76,1 & 67,8 & 56,0 & 66,8 \\
31 & 100 & 84,4 & 73,6 & 80,9 & 68,7 & 57,9 & 58,9 \\
30 & 100 & 83,7 & 75,0 & 80,7 & 71,2 & 57,9 & 52,8 \\
29 & 100 & 83,4 & 73,9 & 81,3 & 74,1 & 60,4 & 54,0 \\
28 & 100 & 84,4 & 73,6 & 80,5 & 73,1 & 62,8 & 55,1 \\
27 & 100 & 85,9 & 69,4 & 80,9 & 63,3 & 65,0 & 58,9 \\
26 & 100 & 81,6 & 68,7 & 80,8 & 62,1 & 64,7 & 60,2 \\
25 & 100 & 81,9 & 65,8 & 80,9 & 61,3 & 65,5 & 56,5 \\
& & & & & & & \\
\hline
\end{tabular}

Tabel C.2

Impliciete rendementen in de reconstructie-analyse met correctie voor de terugstroom van ongediplomeerden in het onderwijs

$\begin{array}{lcc}30-34 \text { jaar } & \text { rendement voor correctie } & \text { rendement na correctie terugstroom } \\ \text { MBO } & 68,3 & 70,4 \\ \text { HBO } & 59,2 & 66,2 \\ \text { WO } & 64,6 & 69,6 \\ & & \\ & & \\ 25-29 \text { jaar } & \text { rendement voor correctie } & \text { rendement na correctie terugstroom } \\ \text { MBO } & 67,5 & 69,7 \\ \text { HBO } & 63,8 & 68,9 \\ \text { WO } & 57,0 & 62,0\end{array}$

